\title{
Calcitonin gene-related peptide receptor as a novel target for the management of people with episodic migraine: current evidence and safety profile of erenumab [Corrigendum]
}

\author{
Giamberardino MA, Affaitati G, Costantini R, et al. J Pain \\ Res. 2017;10:2751-2760.
}

On page 2756, left column, lines 7 and 8: "Patients who previously had failed two preventative medications were excluded." should have been: "Patients who previously had failed more than two preventive medications were excluded."

On page 2756, right column, lines 41-43: "There was a difference of -1.1 days in the main change in monthly migraine days between $70 \mathrm{mg}$ erenumab group and placebo." should have been: "There was a difference of -2.5 days in the mean change in monthly migraine days between $70 \mathrm{mg}$ erenumab group and placebo."

The Journal of Pain Research is an international, peer reviewed, open access, online journal that welcomes laboratory and clinical findings in the fields of pain research and the prevention and management of pain. Original research, reviews, symposium reports, hypothesis formation and commentaries are all considered for publication.
The manuscript management system is completely online and includes a very quick and fair peer-review system, which is all easy to use. Visit http://www.dovepress.com/testimonials.php to read real quotes from published authors. 